\title{
DE MANAGERIAL REVOLUTION IN DE VS EN NEDERLAND IN DE TWINTIGSTE EEUW'
}

\begin{abstract}
The Managerial Revolution in the USA and The Netherlands during the twentieth century

In this article we attempt to assess the timing and the extent of the so-called Managerial Revolution (MR) in the USA and The Netherlands more systematically than has been done in the existing literature. We distinguish three dimensions of the $\mathrm{MR}$ : the separation of ownership and management (1), the rise of a new class of professional managers (2), and the ascendancy of middle managers in corporate hierarchies (3). The third dimension is measured by using national censuses, while our discussion of the first and second ones is based on existing scholarly works. We conclude that managerialism gained ground in the United States rather gradually during the twentieth century, while a $M R$-if any-did only take place in the Netherlands after 1960.
\end{abstract}

In de bedrijfshistorische literatuur is de managerial revolution - opnieuw - een gevleugeld begrip geworden sinds de publicatie van The Visible Hand door Alfred D. Chandler in I977. ${ }^{2}$ Met deze revolutie duidt men de opkomst aan van de door professionele managers bestuurde onderneming. De managerial revolution wordt door Chandler beschreven als een tamelijk lineair verlopend proces, waarbij de management-onderneming als meest efficiënte organisatievorm het eindpunt vormt. ${ }^{3}$ Uit studies van vooral Europese (bedrijfs)historici blijkt echter dat het proces van de managerial revolution toch niet zo rechtlijnig verloopt als Chandler het voorstelt en dat er alternatieve organisatievormen bestaan die niet minder efficiënt zijn. Bekend is het onderzoek naar flexible specialisation van C.F. Sabel, M.J. Piore en J. Zeitlin, waarbij de netwerkstructuur van Noord-Italiaanse familiebedrijven in onder meer de textielindustrie als lichtend voorbeeld fungeert. ${ }^{4}$ In andere studies is gewezen op het (voort)-

1. Met dank aan de redactie, de anonieme referenten en Mila Davids voor hun commentaar op een eerdere versie van dit artikel.

2. A.D. Chandler Jr., The Visible Hand. The Managerial Revolution in American Business (Cambridge Mass. I977). 
bestaan van familiebedrijven en hun nog altijd grote betekenis voor de nationale economie. ${ }^{5}$ Er zijn nog meer kritische kanttekeningen te plaatsen bij de wijze waarop Chandler, maar ook andere onderzoekers, het concept managerial revolution hebben gehanteerd. Hoewel het begrip managerial revolution veelvuldig wordt gebruikt, ontbreekt een eenduidige definitie in de literatuur. Mede daardoor is ook de operationalisering en empirische onderbouwing problematisch. De empirische onderbouwing is bovendien selectief - doordat de analyse doorgaans beperkt blijft tot grote al of niet beursgenoteerde ondernemingen - of ontbreekt geheel. ${ }^{6}$

De managerial revolution verdient naar onze mening een meer uitvoerige en systematische behandeling dan zij tot nu heeft gekregen. Immers, veel

3. Deze interpretatie van Chandler is krachtig aangevochten door verschillende Amerikaanse historisch sociologen (Neil Fligstein, The Transformation of Corporate Control (Cambridge Mass. I990), William G. Roy, Socializing Capital. The Rise of the Large Industrial Corporation in America (Princeton I997) en Harland Prechel, Big Business and the State. Historical Transformation, 1880s-1990s (Albany 2000)). Volgens Chandler is de opkomst van de grote, geïntegreerde ondernemingen vooral het gevolg van de transportrevolutie en sterke productiviteitsstijgingen die voortvloeiden uit de mechanisatie in de industrie. Zijn critici verklaren het verkrijgen van dominantie van corporations vooral uit het streven naar marktcontrole, veranderingen in opvattingen en Amerikaanse wetgeving omtrent corporations en mededinging vanaf de tweede helft van de negentiende eeuw. De rol van de staat en de financiers is voor hen cruciaal. Deze auteurs stellen daarmee ook de verschuiving naar managerial capitalism ter discussie, maar met uitzondering van Prechtel (vooral hij stelt nadrukkelijk dat de capitalists hun macht helemaal niet integraal hebben afgestaan aan de managers), doen de betreffende auteurs echter geen uitspraken over de interne ontwikkeling van de corporations. Zij bieden in dit opzicht daarom geen alternatief voor Chandler. 4. C.F. Sabel en J. Zeitlin, 'Historical alternatives to mass production: politics, markets and technology in nineteenth-century industrialization', in: Past and Present I08 (1985) I33-175; C.F. Sabel en J. Zeitlin (eds.), World of possibilities. Flexibility and mass production in Western industrialization (Cambridge 1997); Andrea Colli, 'Networks of trust, networks of interest. Network analysis and Italian business history', in: Tony Slaven (ed.) Business History, theory and pratice. Proceedings of the Conference of Business History \& Theory. July 1999, Glasgow (Glasgow 2000) I6I-I72.

5. Geoffrey Jones en Mary B. Rose, 'Family Capitalism', in: Business History 35:4 (I993) I-I5; over Nederlandse familiebedrijven: K. Sluyterman en H. Winkelman, 'The Dutch family firm confronted with Chandler's dynamics of industrial capitalism', in: Business History 35:4 (I993) I52-I83; zie voor het debat over familiebedrijven: Doreen Arnoldus, Family, family firm, and strategy. Six Dutch family firms in the food processing industry 1880-1970 (Amsterdam 2002) I5-I8.

6. David J. Jeremy en Douglas A. Farnie, 'The ranking of firms, the counting of employees, and the classification of data: a cautionary note', in: Business History 43:3 (July 200I) IO5-II 8 (noot 4, II6); John Quail, 'Mapping the Managerial Revolution in the U - Definitions, Dating and Demonstrations', in: Tony Slaven (ed.) Business History, theory and pratice. Proceedings of the Conference of Business History \& Theory. July 1999, Glasgow (Glasgow 2000) 222-236; John Quail, 'The proprietorial theory of the firm and its consequences', in: Journal of Industrial History 3:I (2000). 


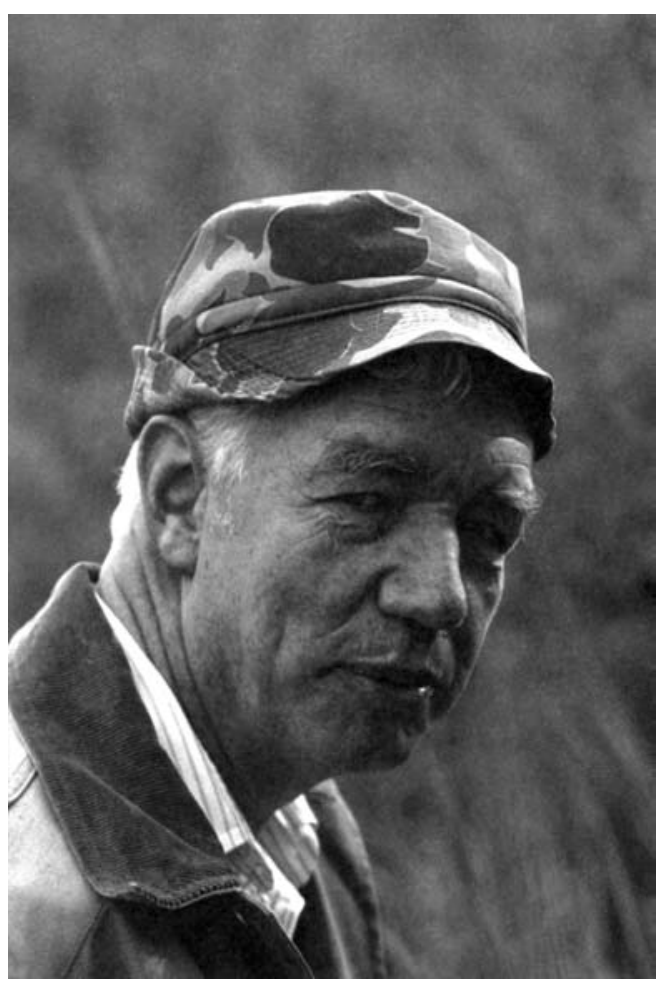

Alfred Dupont Chandler.

Bron: Thomas K.McCraw (ed.),The essential Alfred Chandler: essays toward a historical theory of big business (Boston 1988). beschouwingen over het gedrag van ondernemingen en hun bestuurders in de moderne economie zijn gebaseerd op de aanname van het optreden van deze managerial revolution. Wij zullen het al dan niet optreden van een managerial revolution op verschillende manieren meten. Wij onderscheiden - op basis van de literatuur - drie dimensies van de managerial revolution: de scheiding van eigendom en bestuur, de opkomst van de professionele manager en het ontstaan van een middenkader in ondernemingen. Deze drie dimensies hangen in belangrijke mate met elkaar samen. Toch is het zinnig ze - ook gezien de verschillende populaties waar ze betrekking op hebben - gescheiden te behandelen. Voor het meten van de ontwikkelingen op deze drie dimensies maken wij noodzakelijkerwijs gebruik van verschillende operationalisaties. Bij de scheiding van eigendom en bestuur wordt - in navolging van de geraadpleegde auteurs gekeken naar de spreiding van het aandelenbezit en het aandeel van managers in loondienst in het bestuur. Met betrekking tot de tweede dimensie is, door het concretiseren van de globale impressies van vooral J. Burnham, de aard van de scholing van de bestuurders van grote ondernemingen het belangrijkste meetinstrument. Deze twee dimensies zijn bepaald op basis van een beperkte selectie aan ondernemingen. Voor de derde dimensie (de opkomst van het middle management) baseren wij ons echter, door wederom algemene impressies van één auteur (Chandler) expliciet te maken, op de uitkomsten van nationale beroepstellingen over het (relatieve) aantal middle managers. Hierdoor hebben onze bevindingen op deze dimensie betrekking op de hele populatie van ondernemingen, dus inclusief de vele kleinere (familie-)ondernemingen. Deze werkwijze is, voor zover we hebben kunnen nagaan, niet eerder toegepast bij de bestudering van het fenomeen managerial revolution. Hiermee hopen wij de discussie over de managerial revolution een stap verder te brengen. In onze analyse vergelijken wij bovendien de Verenigde Staten (vs), de (veronderstelde) bakermat van de managerial revolution, en Nederland. Kunnen we spreken van een managerial revolution in deze landen? Zo ja, wanneer kan deze worden gedateerd? 


\section{De scheiding van eigendom en bestuur}

De term managerial revolution vindt zijn oorsprong in het onderzoek naar de scheiding van eigendom en bestuur dat aan het begin van de twintigste eeuw in de vS werd uitgevoerd. ${ }^{7}$ De golf aan fusies en overnames rond I89o en in de jaren I920 verontrustte Amerikaanse politici en wetenschappers. ${ }^{8}$ Het concentratieverschijnsel deed zich het eerst en sterkst voor bij de particuliere spoorwegen en dat was voor de Interstate Commerce Commission (ICC) aanleiding in I923 een onderzoek te laten doen door de hoogleraar politieke economie W.Z. Ripley. ${ }^{9}$ In het rapport betoogde Ripley dat door de spreiding van het aandelenbezit over steeds meer aandeelhouders, het management macht naar zich toe kan trekken en zichzelf kan verrijken ten koste van de aandeelhouder door winsten niet uit te keren als dividend. Deze ideeën verkondigde hij ook tijdens zijn colleges en zij vormden een stimulans voor zijn oud-studenten A.A. Berle en G.C. Means om dit verder uit te zoeken. ${ }^{\text {Io }}$

Berle, vanaf I927 hoogleraar Corporate Law aan de Universiteit van Columbia, en Means ${ }^{\text {II }}$ deden onderzoek naar recente trends in de ontwikkeling van naamloze vennootschappen. ${ }^{\mathrm{I}}$ In hun boek The Modern Corporation and Private Property (I932), signaleerden zij vier belangrijke ontwikkelingen: (I) steeds meer economische activiteiten werden gedaan door vennootschappen, (2) deze vennootschappen werden steeds groter, (3) er was sprake van een toenemende spreiding van het aandelenbezit en (4) als gevolg hiervan trad er een scheiding op van eigendom en control. Met control bedoelden zij de macht om de directie

7. Vergelijk met Yehouda Shenhav, Manufacturing rationality. The engineering foundations of the managerial revolution (Oxford I999) Io (noot 2).

8. Tussen I888 en I903 ontstonden alleen al 303 industriële trusts, op een totaal in I903 van 318. Mabel Newcomer, The big business executive. The factors that made him 1900-1950 (New York I955) 4.

9. Over Ripley: Frederic S. Lee en Warren J. Samuels, 'Introduction: Gardiner C. Means, I896-I988', in: Frederic S. Lee en Warren J. Samuels (eds.) The heterodox economics of Gardiner C. Means. A collection (New York 1992) xv-xxxiii; William Z. Ripley, Wall Street and Main Street (London 1927).

10. In de inleiding van hun boek bedankt Berle Ripley '[...] who must be recognized as having pioneered this area' (A.A. Berle en G.C. Means, The Modern Corporation and Private Property (New York I932)) ix.

11. Over Berle: Jordan A. Schwarz, Liberal: Adolf A. Berle and the Vision of an American Era (Free Press 1987). Over Means: Frederic S. Lee en Warren J. Samuels, 'Introduction: Gardiner C. Means, I896-I988', in: Frederic S. Lee en Warren J. Samuels (ed.) The heterodox economics of Gardiner C. Means. A collection (New York 1992) xv-xxxiii.

12. G.C. Means, 'The Corporate Revolution', in: Frederic S. Lee en Warren J. Samuels (ed.), The heterodox economics of Gardiner C. Means. A collection (New York I992) 3; A.A. Berle en Gardiner C. Means, 'Corporations and the Public Investor', in: American Economic Review 20:I (I930) 54-7I; Gardiner C. Means, 'The Diffusion of Stock Ownership in the United States', in: Quarterly Journal of Economics 44:4 (I930) 56I-600. 
te benoemen en te ontslaan. ${ }^{\mathrm{I}}$ In feite gaat het dus om de mogelijkheid van een aandeelhouder om de samenstelling van het management en daarmee de strategie van het bedrijf te bepalen. Berle en Means stelden dat door de toenemende spreiding van het aandelenbezit, meer bestuursmacht in handen kwam van het management, omdat geen van de aandeelhouders nog voldoende aandelen bezat om deze macht effectief uit te oefenen. Zodoende konden managers deze macht uitoefenen, zonder dat zij formeel (mede-)eigenaar waren. ${ }^{\text {I4 }}$ De juistheid van deze stelling onderzochten Berle en Means overigens niet in hun boek, maar zij richtten zich louter op het meten van de spreiding van het aandelenbezit. In hun redenering volgde uit het een immers het andere.

Voor hun onderzoek naar de mate van spreiding van het aandelenbezit namen Berle en Means de 200 grootste beursgenoteerde Amerikaanse industrie-, nuts- en transportbedrijven (financiële instellingen, zoals banken en verzekeringsbedrijven, telden niet mee). ${ }^{15}$ Berle en Means onderscheidden op basis van het percentage aandelenbezit (de mate van concentratie ofwel de spreiding daarvan) vijf verschillende typen ondernemingen (tabel I). ${ }^{\mathrm{I}}$

TABel 1 Typen van 'control' naar Berle en Means

\begin{tabular}{ll}
\hline Type & $\begin{array}{l}\text { Stemgerechtigde } \\
\text { aandelen (in percentages) }\end{array}$ \\
\hline Particulier eigendom ('privately owned') & 80 of meer \\
Meerderheidsbelang ('majority control') & 50 tot 80 \\
Minderheidsbelang ('minority control') & 20 tot 50 \\
Juridische constructies ('control by means of a legal device') & minder dan 20 \\
Management-onderneming ('management-controlled') & minder dan 5 \\
\hline
\end{tabular}

Bron: A.A. Berle en G.C. Means, The Modern Corporation and Private Property (New York I932) $47-66$.

Deze typen bestrijken feitelijk een continuüm, dat loopt van een bedrijf in handen van een persoon of familie, tot een onderneming met vele tienduizenden aandeelhouders, waardoor de macht de facto in handen ligt van het management. Voor het vaststellen van de mate van spreiding van het aandelenbezit

13. Berle en Means, The modern corporation, 69. '[...] the individual or group who have the actual power to select the board of directors (or its majority), either by mobilizing the legal right to choose them [...] or by exerting pressure which influences their choice'. Vinke gebruikt voor 'control' de term bestuursmacht. P. Vinke, De maatschappelijke plaats en herkomst der directeuren en commissarissen van de open en daarmede vergelijkbare besloten Naamloze Vennootschappen (Leiden I96I) 45.

14. In veel gevallen hadden managers in de VS aandelen in het bedrijf. Volgens de opvatting van Berle en Means was dat echter geen noodzakelijkheid om bestuursmacht uit te oefenen. 15. De rangorde werd bepaald door het vermogen van de beursgenoteerde bedrijven.

16. Berle en Means, The modern corporation, 70. 
gebruikten zij Standard's Corporation Records (later: Standard Q Poor Corporation Records), Moody's Manual van I930 en The New York Times uit de periode I928-I930. Dat deze data fragmentarisch zijn, gaven ze zelf toe. ${ }^{\text {I7 }}$ Berle en Means tekenden verder aan dat het classificeren van de gevallen in vijf groepen een grote mate van onnauwkeurigheid met zich meebracht. Dit heeft hen er overigens niet van weerhouden om vergaande conclusies te trekken, die andere auteurs zonder discussie hebben geaccepteerd. ${ }^{\mathrm{I} 8}$

TABEL 2 Typologie van de 200 grootste niet-financiële bedrijven in de VS op basis van spreiding van het aandelenbezit (1929/1930, 1963 en 1965)

\begin{tabular}{|c|c|c|c|c|c|c|c|}
\hline \multirow[b]{3}{*}{ Type } & \multicolumn{4}{|c|}{ Berle en Means (1932) } & \multirow{3}{*}{$\begin{array}{l}\text { Larner } \\
\left(196_{3}\right)\end{array}$} & \multicolumn{2}{|c|}{ Burch (1965) } \\
\hline & \multicolumn{2}{|c|}{ Vóór herclassificatie } & \multicolumn{2}{|c|}{ Na herclassificatie } & & & \\
\hline & Aantal & Procent & Aantal & Procent & & Type & Procent \\
\hline Particulier eigendom & $\mathrm{I} 2$ & 6 & I2 & 6 & ० & $\begin{array}{l}\text { Vermoedelijk } \\
\text { familiebezit }\end{array}$ & 40,5 \\
\hline Meerderheidsbelang & IO & 5 & IO & 5 & 2,5 & $\begin{array}{l}\text { Waarschijnlijk } \\
\text { familiebezit }\end{array}$ & $\mathrm{I} 7,5$ \\
\hline Juridische constructies & $2 \mathrm{I}$ & IO, 5 & $4 \mathrm{I}$ & $2 \mathrm{I}$ & 4 & & \\
\hline Minderheidsbelang \ & 44 & 22 & 46,5 & 23 & 9 & & \\
\hline $\begin{array}{l}\text { Management- } \\
\text { onderneming }\end{array}$ & $2 \mathrm{I}$ & 10,5 & 88,5 & 44 & 84,5 & $\begin{array}{l}\text { Vermoedelijk } \\
\text { management- } \\
\text { onderneming }\end{array}$ & 42 \\
\hline $\begin{array}{l}\text { Vermoedelijk } \\
\text { minderheidsbelang }\end{array}$ & 29 & I 4,5 & - & - & & & \\
\hline $\begin{array}{l}\text { Vermoedelijk } \\
\text { management- } \\
\text { onderneming }\end{array}$ & 44 & 22 & - & - & & & \\
\hline $\begin{array}{l}\text { Gemeenschappelijk } \\
\text { eigendom }\end{array}$ & I6 & 8 & - & - & & & \\
\hline Speciale situaties* & 3 & $\mathrm{I}, 5$ & 2 & I & & & \\
\hline Totaal & 200 & 100 & 200 & 100 & IO० & & IOO \\
\hline
\end{tabular}

* Bijvoorbeeld in liquidatie.

Bron: Berle en Means, The modern corporation, 94; Gardiner C. Means, 'The Separation of Ownership and Control in American Industry', in: Quarterly Journal of Economics 46: I (I93I) 98 (table II), de reclassificatie staat op 99 (table III); Robert. J. Larner, 'Ownership and control in the 200 largest nonfinancial corporations, I929 and I963', in: American Economic Review 56: 4 (September I966) 781 (table I); Philip H. Burch Jr., The Managerial Revolution reassessed. Family control in America's large corporations (Lexington I972) 70, 98 en Ior; Dennis Leech, 'Corporate ownership and control: a new look at the evidence of Berle and Means', in: Oxford Economic Papers 39 (I987) 534-55I.

17. Berle en Means, The modern corporation, 90.

18. Bekende publicaties die dit idee hebben overgenomen zijn: Daniel Bell, The End of Ideology (New York, I96I) en John Kenneth Galbraith, The New Industrial State (Boston, I967). Zie ook Rafael la Porta, Florencio Lopez-De-Silanes en Adrei Shleifer, 'Corporate ownership around the world', in: The Journal of Finance 54:2 (April I999) 47I-5I7. 
In tabel 2 zijn de resultaten van het onderzoek van Berle en Means samengevat (kolom Berle en Means). Uit de statistische analyse bleek dat 44 procent van de 200 bedrijven als een management-onderneming gekwalificeerd moest worden. In eerste instantie vonden ze echter dat bij slechts Io,5 procent van de bedrijven sprake was van 'management-control', wat niet bepaald op een revolutie wees. Om aan 44 procent te komen, moesten Berle en Means hun onderzoeksmethode op twee punten aanpassen. Ten eerste werd de grote groep twijfelgevallen op basis van 'general street knowledge' alsnog ingedeeld bij groep 3, 4 of $5 .{ }^{19}$ Ten tweede introduceerden ze, als een tussenstap in hun analyse, de begrippen directe en indirecte control. ${ }^{20}$ Door beide aanpassingen schoot groep 5 flink omhoog (zie tabel 2: kolom Berle en Means: Na herclassificatie). ${ }^{2 \mathrm{I}} \mathrm{De}$ managerial revolution was volgens Berle en Means - afgemeten aan de spreiding van het aandelenbezit - rond I930 al zeer ver voortgeschreden in het Amerikaanse bedrijfsleven. ${ }^{22}$

Robert J. Larner gebruikte in zijn onderzoek uit I966 zoveel mogelijk dezelfde definities en onderzoeksmethoden als Berle en Means. Belangrijk is wel dat hij - in afwijking van Berle en Means - de ondergrens voor een controlerend minderheidsbelang stelde op io procent van de stemgerechtigde aandelen in plaats van 20 procent. ${ }^{23}$ Uit Larner's onderzoek blijkt dat in I963 al 84,5 procent van de 200 grootste niet-financiële bedrijven in de vs kon worden geclassificeerd als een management-onderneming (zie tabel 2: kolom Larner). In de top-200 vond hij zelfs geen enkel bedrijf meer dat in handen was van één persoon of familie. Kortom, de managerial revolution naderde, volgens Larner, haar voltooiing. Zijn onderzoek was een welkome ondersteu-

19. Berle en Means, The modern corporation, 92.

20. Indien een andere onderneming een minderheidsbelang had in een ander bedrijf werd gekeken naar onder welk type de aandeelhouder viel. Dit was overigens bij slechts 5 bedrijven nodig. Berle en Means, The modern corporation, Io9.

21. Dennis Leech, 'Corporate ownership and control: a new look at the evidence of Berle and Means', in: Oxford Economic Papers 39 (I987) 534-551.

22. In I934 plaatste W.L. Crum al vraagtekens bij de kwantificering van het onderzoek van Berle en Means. W.L. Crum, 'On the alleged concentration of economic power', in: The American Economic Review 24:I (March I934) 69-83.

23. Bij een strikte definitie van een management-onderneming, te weten het aandeelhouderschap is dermate gespreid dat er van die zijde geen significante invloed op het management kan worden uitgeoefend, zou dit betekenen dat Larner een onderneming minder snel als management-onderneming classificeerde dan Berle and Means. Larner heeft zelf geen berekeningen uitgevoerd om de effecten van zijn wijzigingen vast te stellen. 'In the present study a firm is classified as immediately controlled by minority stock ownership if Io per cent or more of its voting stock is held by an individual, family, corporation, or group of business associates'. Robert J. Larner, 'Ownership and control in the largest nonfinancial corporations, I929 and I963', in: The American Economic Review 56:4 (September I966) 777-788; Robert J. Larner, Management Control and the Large Corporation (New York I970). 
ning voor Berle en Means die in een in I967 verschenen herziene versie van hun studie, ondanks de kritiek op de cijfermatige onderbouwing, vasthielden aan hun eerder getrokken conclusie. ${ }^{24}$

In I972 plaatste Phillip H. Burch kritische kanttekeningen bij het onderzoek van Berle en Means en Larner. ${ }^{25}$ De bronnen die Berle en Means hadden gebruikt gaven, aldus Burch, zelden goede of betrouwbare informatie. Een ander belangrijk punt van kritiek was dat zij alleen gegevens van beursgenoteerde bedrijven gebruikten zodat veel grote familiebedrijven, die meestal geen notering hadden, buiten beschouwing bleven. Hiermee legde Burch een vinger op de gevoelige plek: wie slechts de allergrootste, beursgenoteerde ondernemingen in beschouwing nam, maakte het zichzelf gemakkelijker een bevestiging te vinden van de managerial revolution.

Burch onderzocht zelf de Amerikaanse top-300 in I965 op basis van de jaarlijkse ranglijst van Fortune. ${ }^{26}$ Hij verzamelde echter ook gegevens over niet-beursgenoteerde, merendeels grote familiebedrijven. ${ }^{27}$ Burch gebruikte twee criteria om de mate van control vast te stellen: het aandelenbezit en zitting hebben in de directie (board) of een top-managementpositie bekleden (bijvoorbeeld: chief executive officer (ceo), een criterium dat Berle en Means en Larner niet hadden meegenomen. Volgens Burch kan men bestuursmacht uitoefenen van binnenuit of van buitenaf, maar de meest directe vorm is van binnenuit door lidmaatschap van een raad van bestuur of raad van commissarissen (in de VS: de board of directors). Combinatie van de resultaten van het onderzoek naar de spreiding van het aandelenbezit en de samenstelling van de board of directors gaf, volgens Burch, een betere indicatie waar de bestuursmacht in een onderneming lag.

Hij was, net als Berle en Means, niet in staat om altijd met zekerheid het aandelenbezit vast te stellen en gebruikte daarom verschillende categorieën lopend van probably family tot probably management. Als ondergrens voor een controlerend minderheidsaandeel (working control) gebruikte Burch niet Io procent, zoals Larner, maar 4 tot 5 procent. In tabel 2 (kolom Burch) zijn de

24. A.A. Berle en G.C. Means, The Modern Corporation and Private Property (New York I967, revised edition) xxx.

25. Philip H. Burch Jr, The Managerial Revolution Reassessed. Family Control in America's Large Corporations (Lexington I972). Burch noemt twee publicaties voor I972, die het onderzoek van Berle en Means hebben overgedaan: de studie van Robert J. Larner (zie hiervoor noot 23) en die van de journalist Robert Sheehan, 'Proprietors in the World of Big Business', Fortune (i5 June i967).

26. Hierbij wordt het vermogen en/of de omzet van de onderneming genomen. Het gebruik van andere criteria, bijvoorbeeld aantal werknemers of toegevoegde waarde, leidt natuurlijk tot andere ranglijsten.

27. Hij gebruikte de volgende bronnen: Fortune (I950-najaar I97I), Time (I955-najaar I97I), Business Week (I955-najaar I97I), Forbes (I955-najaar I97I) en New York Times (I960najaar I97I). 
resultaten van zijn studie samengevat voor alleen de top-200, om een vergelijking met Berle/Means en Larner mogelijk te maken. Het is begrijpelijk dat Burch een veel groter percentage niet-managementondernemingen c.q. familiebedrijven vond dan Larner (maximaal 58 procent tegen maximaal i5 procent). Op basis van zijn studie concludeerde Burch dat de managerial revolution nog helemaal niet voltooid was en dat dit voorlopig ook nog niet zou gebeuren. ${ }^{28}$ Dat kwam, aldus Burch, omdat het idee dat familiebedrijven naarmate ze ouder waren (en groter werden) geleidelijk zouden overgaan in handen van managers, ook niet juist was gebleken. ${ }^{29}$

Het staat al met al bepaald niet vast dat er zich in de twintigste eeuw bij grote ondernemingen in de vs een integrale en snelle scheiding van eigendom en bestuur heeft voorgedaan.

\section{Nederland}

Dit roept de vraag op in hoeverre een dergelijke ontwikkeling in het veelal meer kleinschalige Nederlandse bedrijfsleven zichtbaar is geworden.Voor zover bekend is het bestaande Nederlandse onderzoek over de scheiding van eigendom en bestuur beperkt en impressionistisch. De literatuur die er is - met name die van K. Sluyterman en H. Winkelman - wijst uit dat ook het grootbedrijf in ieder geval tot I930 door families werden gedomineerd. ${ }^{30}$ Beide auteurs stelden vast dat van de Ioo grootste Nederlandse industriële ondernemingen in I930 (gemeten op basis van balanswaarde) er veertien in handen waren van families die eigendom en bestuur combineerden. Zeventien waren als familiebedrijf begonnen, maar hadden zich in I930 tot beursgenoteerde ondernemingen omgevormd. De familie bleef in die ondernemingen wel de leiding behouden. Nog eens 30 ondernemingen waren eveneens als familiebedrijf begonnen, maar daar hadden inmiddels buitenstaanders een aandeel in de leiding gekregen. In bijna al die gevallen bleef de familie echter een dominante positie in de leiding behouden. Het komt erop neer dat 6I - dus bijna tweederde - van de Ioo grootste industriële bedrijven in Nederland in I930 familiebedrijven waren of voortkwamen uit familiebedrijven. Van de overige 39 ondernemingen waren er vijf coöperaties en negentien zouden kunnen worden omschreven als persoonlijke ondernemingen, aangezien één

\footnotetext{
28. Burch, The Managerial Revolution Reassessed, I05.

29. 'As family- and financier-controlled enterprises grew in size and age they became managerial'. In: Chandler, The Visible Hand, Io.

30. Sluyterman en Winkelman, 'The Dutch family firm confronted with Chandler's dynamics of industrial capitalism, I890-I940', I52-I83. De selectie is gebaseerd op balanstotalen. K. Sluyterman, Kerende kansen. Het Nederlandse bedrijfleven in de twintigste eeuw (Amsterdam 2003) I38-I39.
} 
of twee mensen besloten om een onderneming op te zetten en het klaarspeelden om genoeg geld bij elkaar te krijgen binnen een informeel circuit van familie en kennissen. Zelfs als de initiatiefnemers in loondienst waren, kwam het toch nog vaak voor dat ze werden opgevolgd door hun zonen. Slechts zes ondernemingen werkten met managers en financiering via de aandelenbeurs. De resterende negen waren ondernemingen die ergens tussen een persoonlijk en een door managers geleide onderneming in zaten.

In zijn in I96r gepubliceerde onderzoek naar de maatschappelijke plaats en herkomst van directeuren en commissarissen rond I950 concludeerde de socioloog P. Vinke dat de scheiding tussen eigendom en bestuur nog steeds beperkt was in het Nederlandse bedrijfsleven. ${ }^{3 \mathrm{I}}$ Hij vermoedde althans dat dit gold voor de totale groep van alle NV's in Nederland (circa I9.000 in getal). Zijn dissertatie had betrekking op een kleine steekproef van 295 open en 309 besloten Nv's en omvatte I.930 directeuren en 2.377 commissarissen. ${ }^{32}$ Vinke stelde - weinig verrassend - vast dat in de open Nv's de scheiding van bestuur en eigendom zich het verst had doorgezet. Zonder zijn bron prijs te geven, hij verwijst slechts naar de medewerking van 'enkele officiële instanties', meldde Vinke enkele met de Amerikaanse onderzoekingen vergelijkbare gegevens omtrent een subselectie uit zijn steekproef, ter grootte van I57 open Nv's. De overgrote meerderheid van de bestuurscolleges (directeuren en commissarissen) van deze Nv's (79 procent van de Nv's met een kapitaal van I tot 5 miljoen gulden, 94 procent van de Nv's met een groter kapitaal) had in I953 Io procemt of minder van het aandelenkapitaal van de betreffende onderneming in bezit. ${ }^{33}$ Dit wijst er op dat er binnen deze beperkte en waarschijnlijk tamelijk willekeurig samengestelde groep de management-onderneming volgens de door de Berle en Means en hun navolgers gehanteerde maatstaf anno I953 dominant was. Volgens Vinke liet een vergelijking van de Nederlandse cijfers met die van de vs zien '[...] dat de verhoudingen hier te lande soortgelijk zijn als die in de Verenigde Staten' ${ }^{34}$ Hij voegde er meteen aan toe dat er in Nederland nog altijd zeer veel ondernemingen waren waarvan de directeuren zelf eigenaar waren. 'Daarom zou het onjuist zijn om de betekenis van de scheiding van bestuur en eigendom in de onderneming te over-accentueren'. ${ }^{35}$

31. Vinke, De maatschappelijke plaats, 23.

32. Open naamloze vennootschappen hadden een beursnotering, besloten vennootschappen niet. De besloten NV's waren merendeels familiebedrijven.

33. Vinke, De maatschappelijke plaats, 40, 52-54 en 275-276 (tabel Iv).

34. Vinke verwijst in zijn onderzoek naar de cijfers van Berle en Means. Ook Vinke vraagt zich af of hun steekproef representatief is omdat deze betrekking heeft op alleen de allergrootste Amerikaanse ondernemingen. Omdat er naar zijn mening in Nederland geen gegevens beschikbaar waren over de spreiding van aandelen verrichte hij zelf een verkennend onderzoek. Vinke, De maatschappelijke plaats, 53-54.

35. Vinke, De maatschappelijke plaats, 233. 
Een alternatieve meetmethode, die is toepast op alle Nederlandse beursgenoteerde (niet-financiële) ondernemingen, suggereert dat de scheiding tussen eigendom en bestuur bij Nederlandse beursgenoteerde ondernemingen na I960 wel aanzienlijk is toegenomen. A. de Jong en A. Röell hebben recentelijk de familie-invloed binnen deze ondernemingen gemeten in drie steekjaren, I923, I958 en I993. Zij deden dit op basis van twee criteria: (I) de aanwezigheid van leden van de raden van bestuur en commissarissen met dezelfde achternaam als de oprichtersfamilie en (2) het voorkomen van verschillende leden in deze bestuursorganen met dezelfde achternaam. ${ }^{36}$ Tussen I923 en I958 daalden deze indicatoren slechts marginaal, maar tussen i958 en I993 was de daling werkelijk 'dramatisch', te weten van circa 30 tot 6 procent van alle ondernemingen voor beide criteria. In I993 voldeed nog maar iets meer dan io procent van de besturen van de geselecteerde ondernemingen aan één of beide criteria.

Zowel de Amerikaanse als de Nederlandse gegevens over de scheiding van eigendom en bestuur hebben vrijwel steeds alleen betrekking op de (grootste) beursgenoteerde ondernemingen, hetgeen een belangrijke beperking op het generaliseren van de bevindingen betekent. Het is daarbij goed te bedenken dat het tot stand komen van (open) naamloze vennootschappen (corporations in de VS), de vaak daarmee gepaard gaande spreiding van het aandelenbezit en de samenstelling van het bestuur van die ondernemingen maar ten dele goede indicatoren zijn voor het traceren van een toenemende scheiding tussen eigendom en bestuur. Maurice Zeitlin heeft het Amerikaanse debat in I974 verbreed door middel van een overzichtsstudie. ${ }^{37}$ Daarin refereert hij niet alleen aan verschillende weinig bekende studies over de scheiding van eigendom en bestuur met resultaten die afwijken van die van Berle en Means, maar stelt hij ook de empirische basis, de relevantie van de gehanteerde formele criteria en conceptualisering van de verschillende onderzoeken ter discussie. Ook met een aandelenbezit van minder dan tien of vijf procent konden bepaalde individuen of families nog steeds grote invloed op het bedrijfsbeleid uitoefenen. Verder waren veel grote ondernemingen in de vS volgens hem sterk afhankelijk van banken en andere financiële instellingen zodat de classificatie management controlled veelal niet op zijn plaats was. Zonder zelf met een berekening te komen, concludeert Zeitlin dat: '[...] the "separation of ownership and control” may well be one of those rather critical, widely accep-

36. Abe de Jong en Ailsa Röell, 'Financing and control in the Netherlands: an historical perspective', in: R. Morck (ed.), The History of Corporate Ownership: The Rise and Fall of Great Business Families N B E R Conference Volume (Chicago, te verschijnen). De selectie is exclusief ondernemingen waarvan alleen de obligaties aan de beurs genoteerd waren. Met aangetrouwde familie is in de twee gehanteerde criteria logischerwijs geen rekening gehouden. 37. Maurice Zeitlin, 'Corporate Ownership and Control: The Large Corporation and the Capitalist Class', in: The American Journal of Sociology 79:5 (March 1974) I073-III9. 
ted, pseudofacts with which all occasionally have found themselves burdened and bedeviled' ${ }^{38}$

Zeker in Nederland droegen juridische constructies, ondanks de spreiding van het aandelenbezit, bij aan het in stand houden van de band tussen eigendom en bestuur. Met name D. Arnoldus heeft er op gewezen dat het toelaten van 'externe' aandeelhouders in veel gevallen bij Nederlandse familie NV's niet leidde tot een scheiding van eigendom en bestuur. ${ }^{39}$ Het nieuwe eigendom werd weliswaar gescheiden van het bestuur, maar dan wel gepaard gaande met bescherming van de oude eigenaars. Die bescherming kon verschillende vormen aannemen. Een daarvan was de oprichting van een administratiekantoor. Dit kantoor beheerde de uitgegeven aandelen en gaf (verhandelbare) certificaten van deze aandelen uit. De zeggenschap van de aandelen bleef op deze wijze in handen van het administratiekantoor dat niet toevallig geleid werd door de oorspronkelijke familie. Daarnaast kon gebruik worden gemaakt van de zogenaamde oligarchische clausule. Door de uitgifte van een beperkt aantal prioriteitsaandelen met het recht bindende benoemingen voor commissarissen te doen, en deze aandelen in handen van de oorspronkelijke eigenaarfamilie te houden, behield de oorspronkelijke familie een groot deel van haar controle. Ook de gelaagde bestuursstructuur met een raad van commissarissen en een raad van bestuur of een raad van beheer maakte het mogelijk een ongewenste scheiding tussen eigendom en zeggenschap te voorkomen. Formeel werd de raad van bestuur benoemd door de raad van commissarissen, die op haar beurt benoemd werd door de aandeelhouders. Met behulp van de oligarchische clausule konden de benoemingsrechten worden geconcentreerd in handen van een selecte groep aandeelhouders, doorgaans de (oud)familiedirecteuren. Een dergelijke beperking van zeggenschap van nieuwe aandeelhouders vond ook plaats in de publieke, niet familie-Nv's. De gewoonte ontstond dat de raad van commissarissen door coöptatie tot stand kwam.

Kortom, zelfs als er volgens de formele criteria die de diverse, vooral Amerikaanse onderzoekers hebben gehanteerd sprake was van een sterke scheiding van eigendom en bestuur, was het heel goed denkbaar dat de macht van de gesalarieerde managers sterk werd ingeperkt door de invloed van andere belanghebbenden zoals financiers en (familie)aandeelhouders. Dit betekent dat een in de tijd toenemende scheiding van eigendom en bestuur volgens de formele criteria hooguit een tendens aangeeft, absolute waarde kan aan die cijfers niet worden toegekend.

38. Zeitlin, 'Corporate Ownership and Control', I073-III9.

39. D. Arnoldus, 'Opvolging en strategie in Nederlandse familiebedrijven circa I880I970', in: NEHA-Jaarboek voor economische, bedrijfs- en techniekgeschiedenis 65 (2002) 206. 


\section{De opkomst van de professionele managers}

Berle en Means noemden de door hen waargenomen veranderingen the corporate revolution. ${ }^{40}$ Hun theorie kreeg pas het etiket managerial revolution opgeplakt door de voormalige Trotskist James Burnham. ${ }^{4 \mathrm{I}}$ Burnham kwam in I94I, toen hij afscheid had genomen van zijn linkse ideeën, tot de conclusie dat het eindstadium van het kapitalisme niet het socialisme zou zijn, maar managerialism. Zijn opvatting verwerkte hij in The Managerial Revolution or What is happening in the world now (I94I). In zijn boek betoogde Burnham dat er sinds I9I4 een sociale revolutie gaande was door de opkomst van een geheel nieuwe klasse, namelijk een van professionele managers. Deze managers zouden uiteindelijk, aldus Burnham, ook de nieuwe machthebbers in de samenleving zijn. Hierdoor zou een nieuw type samenleving ontstaan: de managerial society. Met managers bedoelde Burnham dan de 'echte' managers: zij die verantwoordelijk waren voor het feitelijke productieproces. ${ }^{42}$ De brede interpretatie van Burnham heeft ook in Nederland de nodige navolgers gekregen. ${ }^{43}$

De studie van Burnham is impressionistisch en bevat geen enkele operationalisering of empirische onderbouwing. Hetzelfde geldt overigens voor Chandler. Deze stelt dat de opkomst van managerial hierachies de vraag deed toenemen naar professionalisering van het management. Deze vraag naar professionalisering manifesteerde zich onder meer in de opkomst van business schools, van specifieke vaktijdschriften en beroepsorganisaties. Uit Burnhams boek kan men afleiden dat ook hij sterk onder de indruk was van de explosieve toename van afgestudeerden van business schools in de VS. Op basis van de impressies van Burnham en Chandler kan de hypothese worden gefor-

40. Berle en Means, The modern corporation, vii.

41. James Burnham, The Managerial Revolution or What is happening in the world now? (New York I94I, gebruikt is de versie van London I942). Over Burnham: Daniel Kelly, James Burnham and the Struggle for the World (Wilmington 2002).

42. Burnham, Managerial revolution, 68, 73, 78 .

43. Het boek van Burnham bleef in ons land niet onopgemerkt, want al in 1947 verscheen een Nederlandse vertaling (James Burnham, Machtsvorming der bewindvoerders: hoe in de huidige maatschappij de bewindvoerders de macht in handen krijgen (Den Haag, [I947]). Uit de kritieken van onder meer J. de Kadt, P. Kuin en P.J. Bouman blijkt dat zij zich grotendeels konden vinden in Burnhams gedachtegang dat de scheiding van bestuur en eigendom in de onderneming consequenties had voor de ontwikkeling van de maatschappelijke structuur, vooral voor de maatschappelijke plaats van de manager. Vinke, De maatschappelijke plaats, I2-I5; P.J. Bouman, 'De maatschappelijke functie van de moderne ondernemer', in: Socialisme en Democratie (I947) 38-43; J. de Kadt, 'James Burnham en zijn leermeesters "The Machiavellians"', in: Socialisme en Democratie (I947); J. de Kadt, 'Karakteristiek van het Tijdperk: “The Managerial Revolution”, in: Socialisme en Democratie (I947) IO7-I20; J. de Kadt, 'Confrontatie met de werkelijkheid', in: Socialisme en Democratie (I947) I8I-I93; P. Kuin, 'Verschuiving van maatschappelijke macht', in: Folia civitatis 9:4 (I955). 
muleerd dat de managerial revolution zich manifesteerde in een substantiële toename van het aantal managers die niet alleen een hogere (academische) scholing hadden genoten (want dat was een algemeen fenomeen), maar ook in het voltooien van een specifieke academische managersopleiding. Heeft een dergelijke ontwikkeling zich inderdaad voltrokken en zo ja, in welke mate?

In I88I werd de eerste Amerikaanse business school opgericht (de Wharton School of Finance), in I9I4 bestonden er al 25 en in I928 al 89. Het aantal ingeschreven studenten steeg tussen ig25 en I928 van 36.000 naar 67.000. ${ }^{44}$ Op grond van de zojuist geformuleerde hypothese, zouden de afgestudeerden van deze business schools na I9I4 doorgedrongen zijn tot de top van het bedrijfsleven en aldus een nieuwe elite zijn gaan vormen. Om dit vast te kunnen stellen is het nodig om gegevens te hebben over de opleiding van Amerikaanse topmanagers.

De meest relevante studie op dit terrein is die van Mabel Newcomer uit I955. Haar onderzoek betrof de sociale achtergrond van de chief executive officer (ceo) en de president (dit kon een en dezelfde persoon zijn) binnen een populatie van 428 bedrijven, zijnde de grootste in drie steekjaren: I900, I925 en I950. ${ }^{45}$ Uit haar onderzoek blijkt inderdaad, zoals mocht worden verwacht, een algemene toenemende scholing van de leiders van de grootste bedrijven in de eerste helft van de twintigste eeuw (tabel 3). Echter, anno I950 had toch nog maar I6,4 procent van de topmanagers een voltooide academische opleiding, waaronder zich veel juristen en ingenieurs bevonden. Slechts weinigen hadden een specifieke academische managersopleiding aan een business school gevolgd. Newcomer concludeerde: 'Graduate study in business administration has not been generally available, even to the I950 generation, and consequently graduate degrees in business administration are few' ${ }^{46}$ Andere onderzoeken bevestigen de beperkte betekenis van de academische vorming aan business schools van Amerikaanse topmanagers tot I950. ${ }^{47}$ Zelfs in I979 had nog minder dan een kwart (circa 22 procent) van de presidents van de Ioo grootste Amerikaanse ondernemingen een afgeronde opleiding als master of business administration (м вА) achter de rug (tegen een magere drie procent in I948). ${ }^{48}$ Van de naoorlogse periode is verder bekend dat het binnen het Ame-

44. F.M.M. de Goey, 'Intellectueel erfgoed. Bedrijfsgeschiedenis in de Verenigde Staten en Nederland, I925-I940', in: Jaarboek voor de Geschiedenis van Bedrijf en Techniek Io (I993) 76-79.

45. Mabel Newcomer, The big business executive (New York I955). Selectiecriteria waren: voor I900 alle ondernemingen met meer dan 25 miljoen dollar; voor i925 50 miljoen dollar en voor I950 75 miljoen dollar (II).

46. Newcomer, The big business executive, 75 .

47. Richard S. Tedlow, Kim Eric Bettcher en Courtney A. Purrington, 'The Chief Executive Officer of the Large American Industrial Corporation in I9I7', in: Business History Review 77:4 (Winter 2003) 687-70 en Neil Fligstein, Transformation, 28I (table 8.8). 
rikaanse middenkader toen regel werd dat de posities van de general foremen (degenen die een trapje hoger in de hiërarchie stonden dan de gewone foremen) vervuld werden door ingenieurs. ${ }^{49}$

Tabel 3 Het opleidingsniveau van Amerikaanse topmanagers tussen 1900 en 1950 (in percentages)

\begin{tabular}{lccc}
\hline & 1900 & 1925 & 1950 \\
\hline Grammar school & 24 & 22,9 & 4,5 \\
High school & 36,7 & 26 & 20,6 \\
College: no degree & I0,8 & II, 6 & I3,3 \\
College: Ist degree & $2 \mathrm{I}$ & 25,6 & 45,3 \\
Graduate & 7,6 & $\mathrm{I} 4$ & $\mathrm{I} 6,4$ \\
& $\mathrm{~N}=3 \mathrm{IO}$ & $\mathrm{N}=326$ & $\mathrm{~N}=869$ \\
\hline
\end{tabular}

Bron: Mabel Newcomer, The big business executive. The factors that made him 1900-1950 (New York I955) 68.

Nederlandse auteurs zijn tot min of meer vergelijkbare bevindingen gekomen over de scholing en vorming van managers. In zijn eerder aangehaalde studie concludeerde Vinke $\mathrm{e}^{5 \circ}$ dat van alle in het onderzoek opgenomen directeuren en commissarissen rond I950 respectievelijk 26 en 38 procent een academische opleiding hadden voltooid. Dat is aanmerkelijk hoger dan de Amerikaanse cijfers van Newcomer. Echter, Vinke baseerde zich op een kleine, niet representatieve steekproef van beursgenoteerde ondernemingen. Volgens een onderzoek van socioloog H.A. Becker bezat in I960 slechts vijf procent van de Nederlandse managers (topmanagers en middle managers) een academische graad. ${ }^{\text {5I }}$ Het verschil met de percentages van Vinke kan mede verklaard worden door het meenemen van de middle managers door Becker (zie hieronder voor beschouwingen over de moeilijke definiëring van deze categorie).

Deze bespiegelingen laten nog onverlet welke opleiding de hooggeschoolde managers dan precies hadden genoten. Evenals Newcomer voor de vs had vastgesteld, had het overgrote deel van de Nederlandse managers geen specifieke academische managementopleiding gevolgd. In Nederland was rond I950 slechts drie procent van de directeuren met een academische graad geen

48. Fligstein, Transformation, 28I (table 8.8: cijfers exclusief presidents waarvan de opleiding onbekend is).

49. Middle Management in USA: seine Stellung und seine Förderung: Reisebericht einer deutschen Studiegruppe, RKw-Rationalisierungs-Kuratorium der Deutschen Wirtschaft, Auslandsdienst, Heft 64 (München I958).

50. Vinke, De maatschappelijke plaats, 242 en 70. Deze gegevens zijn gebaseerd op opgaven in de effectengidsen.

51. H.A. Becker, Opvolging van managers. Simulatie van enkele ontwikkelingen in de Nederlandse managers-groepering tussen 1960 en 1980 (Den Haag I969) 6I. 
jurist of ingenieur, bij de commissarissen was dat zes procent. ${ }^{2}$ De verklaring daarvoor is dat begin jaren zestig het onderwijs voor managers in de vs al een hoge vlucht had genomen, maar vergelijkbare instellingen in Nederland stonden toen nog aan het begin van hun ontwikkeling. Onder de academische gevormde managers uit het onderzoek van Becker scoorden exacte wetenschappen (4I procent), rechten (27 procent) en economie (I6 procent) nog het hoogst. ${ }^{53}$ Becker geloofde dan ook niet dat het managersberoep ooit zou uitgroeien tot een professie, zoals verscheidene waarnemers dachten. ${ }^{54}$

Op basis van het beschikbare materiaal moet worden vastgesteld dat in tegenstelling tot de voorspellingen, noch in de vs noch in Nederland omstreeks I950 sprake was van de opkomst van een nieuwe managersklasse die voor de uitoefening van hun taak een specifieke academische managementopleiding hadden gevolgd.5

\section{Het middenkader in bedrijven}

De kern van de managerial revolution is in de ogen van Chandler de professionalisering van het management. In de vorige paragraaf hebben wij laten zien dat de grote meerderheid van de (top)managers in de VS in ieder geval tot 1950 geen academische opleiding had gevolgd. Chandler's stelling dat er tussen I840 en I950 (de periode van onderzoek in The Visible Hand) een managerial revolution had plaatsgevonden, kent echter ook nog een andere dimensie, namelijk de opkomst van het middenkader. In de bedrijven van vóór I840 bestond er volgens hem nog geen managerial hierarchy, waarbij een board of directors het middenkader aanstuurde, dat zelf weer lager geplaatste managers (zoals foremen en bazen) controleerde. ${ }^{56}$ Voor Chandler vormt het ontstaan van

\footnotetext{
52. Vinke, De maatschappelijke plaats, 292.

53. Becker, Opvolging van managers, 4-5.

54. Becker, Opvolging van managers, I58-I68.

55. Na Vinke en Becker zijn in Nederland meerdere studies verschenen van met name sociologen, waarin de diverse aspecten van het fenomeen managerial revolution zijn onderzocht. Het betreft onder meer onderzoek naar verwantschapsrelaties, de sociale mobiliteit, de professionalisering en de rekrutering van het management. In het algemeen treft men daar een kritische houding aan ten aanzien van het concept van de managerial revolution. T. van den Berge en M. Fennema, 'Verwantschapsstructuren in de financieel-economische elite', in: Sociologisch Tijdschrift II: 4 (februari I985) 727-752; Van Baalen, Management en Hoger Onderwijs (Rotterdam I995); P.J. van Baalen, The social shaping of the early Dutch management schools. Professions and the Power of Abstraction (paper); G.G. Beekenkamp, President-directeuren, posities en patronen. Een studie naar de rekrutering van de leiders van de 250 grootste ondernemingen in Nederland (Bezorgd door J. Dronkers \& T. Dronkers-Vlaming) (Amsterdam 2002). 56. Vgl. Lee E. Preston and James E. Post, 'The Third Managerial Revolution', in: The Academy of Management Journal I7:3 (September 1974) 476-486.
} 
het middenkader dan ook de feitelijke kern van de managerial revolution. 'The tasks of the managers on the lower level who had charge of the operating units did not differ greatly from those of men who owned and managed a single independent factory or commercial office. But the tasks of the middle managers were entirely new. Middle managers had to pioneer in the ways of modern administrative coordination'.57

Maar wat wordt in dit verband bedoeld met het middenkader? Kan het middenkader wel duidelijk worden onderscheiden van andere groepen managers $?^{58}$ Amerikaanse managementhandboeken maken een op het oog simpele en ondubbelzinnige indeling van de managementhiërarchie. ${ }^{59}$ First-line managers of supervisors vormen het laagste niveau en zijn verantwoordelijk voor het managen van het productiepersoneel (voorlieden vallen bijvoorbeeld onder deze categorie). Daarboven staan de middle managers die de lagen tussen het lager management en het topmanagement bevolken. Het topmanagement tenslotte, bestaat uit de board of directors (presidents, vice-presidents, officers) waarbij de chief executive officer (ceo) de dagelijkse leiding heeft. ${ }^{60}$ In de praktijk blijkt het echter zeer lastig deze indeling toe te passen: de precieze afgrenzing van het middenkader naar boven en onder is ongewis. ${ }^{61}$ Zo kwam een gezelschap van Duitse arbeidsdeskundigen tijdens een studiereis in I955 tot de conclusie dat in de VS alle managers onder de top tot het middle management werden gerekend; de term lager management werd nauwelijks gebruikt. ${ }^{62}$ De studie laat ook zien dat de definitie van een middle manager door de jaren heen veranderde. Na de Tweede Wereldoorlog vond in de Vs een opwaardering van het middenkader plaats (onder meer door de hogere scholing die in de vorige paragraaf is behandeld), waarbij foremen uitdrukkelijk tot het (middle) management werden gerekend. ${ }^{63}$ De samenstelling van de groep is zodoende in de loop van de tijd veranderd. In dit perspectief zou Chandler's

57. Chandler, The Visible Hand, 4II.

58. Vgl. Becker, Management, 44-46. Becker trekt de grens bij de categorie 'bazen': daarboven staan de middenmanagers: bedrijfsleiders en 'overige beleidvoerende en leidinggevende personen in bedrijven'. Zie ook: Becker, Opvolging van managers, I-5.

59. Zie bijvoorbeeld Stephen P. Robbins en Mary Coulter, Management (Upper Saddle River 2002, 7e druk) 5 .

6o. Het systeem van een unitaire board komt in Nederland niet voor. Een dergelijke board is het best te omschrijven als een combinatie van een raad van bestuur en een raad van commissarissen, waarin zowel non-executive directors als executive directors plaatsnemen.

61. Emanuel Kay, The Crisis in Middle Management (New York 1974) 4-5; Michael Broussine and Yvonne Guerrier, Surviving as a Middle Manager (London \& Canberra I993) 5-6 en Yves-Frédéric Livian, 'Introduction', in: Yves-Frédéric Livian en John G. Burgoyne (eds.), Middle Managers in Europe (London 1997) 4.

62. Middle Management in USA. De arbeidsdeskundigen waren werkzaam bij onderzoekinstituten, grote ondernemingen (DEMAG en Siemens) en de deelstaat Baden-Würtemberg. 63. Middle Management in USA, 34. 
stelling dat het middenkader het 'nieuwe' uitmaakte van de managerial revolution afhankelijk van de tijdsperiode op verschillende manieren dienen te worden gemeten. Bij Chandler ontbreekt overigens iedere kwantificering van de opkomst van het middenkader, zodat zijn conclusie als zou de revolutie omstreeks I950 zijn voltooid, in de lucht blijft hangen. Daarom wordt hieronder een poging gedaan de veronderstelde opkomst van het middenkader in de VS en Nederland te meten met behulp van nationale beroepstellingen.

Deze bron heeft een belangrijk voordeel. Anders dan in de vorige paragrafen aangehaalde onderzoeken, die steeds zijn gebaseerd op een beperkte én selecte steekproef (bijvoorbeeld: alleen grote beursgenoteerde Nv's), hebben deze cijfers betrekking op vrijwel het complete bedrijfsleven. ${ }^{64}$ De populatie omvat zodoende alle bedrijven in de nijverheid en dienstensector; de kleine, middelgrote en grote bedrijven; familiebedrijven en Nv's, geleid door zelfstandigen en directeuren in loondienst.

Op grond van de theoretische inzichten met betrekking tot de managerial revolution is het te verwachten dat in de loop van de twintigste eeuw het zelfstandig ondernemerschap een aanhoudend dalende trend laat zien in de tellingen. Tegelijkertijd zou het aandeel van de (middle) managers in de beroepsbevolking een aanhoudende stijging moeten vertonen. Om de theorie te toetsen zijn Amerikaanse en Nederlandse statistische gegevens nader onder de loep genomen.

Helaas laten de Amerikaanse statistieken het niet toe een duidelijk onderscheid te maken naar zelfstandige ondernemers, topmanagers en middenkader. De enige relevante indicator voor de ontwikkeling van het middenkader die wij hebben kunnen berekenen, betreft de verhouding tussen het aantal foremen en het aantal uitvoerende werknemers. Zoals eerder opgemerkt, rekent Chandler de voorlieden tot het lager management, maar hebben andere auteurs deze categorie juist wel uitdrukkelijk betrokken in hun bespiegelingen over het middenkader - in het bijzonder na de Tweede Wereldoorlog. De op de Amerikaanse beroepstellingen gebaseerde cijfers laten zien dat het aantal foremen ten opzichte van het aantal uitvoerende werknemers vanaf I900 bijna voortdurend is gestegen (zie tabel 4). Tussen I920 en I940 is er een stagnatie te zien, maar daarna is wederom een toename van het relatieve belang van deze categorie managers waar te nemen. Met het nodige voorbehoud kan worden gesteld dat het middenkader aan de 'onderkant' van de organisatie vanaf I900 aan een opmars is begonnen in het Amerikaanse bedrijfsleven, die in I950 zeker nog niet voltooid was. Gezien de lengte van de bestreken periode is hier eerder sprake van een evolutie dan van een revolutie.

64. Alleen de agrarische sector en bepaalde delen van de dienstensector, met name vrije beroepen, zijn buiten beschouwing gelaten. 
TABEL 4 Verhouding van het aantal foremen (voorlieden) ten opzichte van het aantal uitvoerende werknemers in het niet-agrarische bedrijfleven in de VS 1900-1970 (in procenten)

\begin{tabular}{ll}
\hline I900 & $1,6 \%$ \\
I910 & $2,2 \%$ \\
I920 & $2,9 \%$ \\
I930 & $2,9 \%$ \\
I940 & $2,8 \%$ \\
I950 & $3,6 \%$ \\
I960 & $4,7 \%$ \\
I970 & $5,7 \%$ \\
\hline
\end{tabular}

Bron en toelichting: berekend op basis van us Bureau of the Census ; Susan B. Carter [et al.], Historical statistics of the United States on CD-ROM : colonial times to I970 (New York I997) series 233-682. Het aantal foremen is opgegeven binnen de hoofdcategorie 'Craftsmen, foremen, and kindred workers'. Het aantal uitvoerende werknemers is bepaald door het optellen van de genoemde hoofdcategorie exclusief het aantal foremen en de hoofdcategorieën 'operatives and kindred workers' en 'laborers, except farm and mine'. Werknemers in de agrarische sector, professionals, technici, verkoopmedewerkers en bepaalde groepen persoonlijke dienstverleners (met name bedienden in het huishouden, bewakingspersoneel, verpleegsters en horecapersoneel) zijn op deze manier niet meegeteld.

Is dat ook in Nederland het geval? Voor zover bekend zijn de opkomst en ontwikkeling van het middenkader in Nederland niet eerder onderwerp van onderzoek geweest. Om daar meer duidelijkheid over te verschaffen, zijn door ons de beroepstellingen geraadpleegd. In tabel 5 is de relevante informatie over de Nederlandse beroepsbevolking werkzaam in de industrie en de commerciële dienstensector naar positie in het bedrijf samengevat (voor een toelichting van de uitgebreide bewerking van de gegevens zie Appendix). We zijn uitgegaan van de indeling van de beroepsbevolking naar positie in het bedrijf zoals die is gemaakt in de beroepstellingen tot en met I947, waarbij A staat voor zelfstandige ondernemers, ${ }^{65} \mathrm{~B}$ voor directeuren in loondienst, $\mathrm{C}$ voor overig leidinggevend en toezichthoudend personeel en $\mathrm{D}$ voor de uitvoerende werknemers. Onze speciale aandacht gaat uit naar categorie C, wier omvang wij gebruiken als indicator voor het aantal middenmanagers, vandaar dat in de tabel ook de verhouding tussen $\mathrm{C}$ en $\mathrm{D}$ is aangegeven (de verhouding middenmanagers en degenen die zij geacht worden aan te sturen).

65. Met zelfstandige ondernemers worden bedoeld ondernemers die voor eigen rekening en risico leiding geven aan een onderneming. Deze beroepspositie zegt niets over de omvang van de onderneming wat personeel betreft. Dat kan zowel een kleine als een zeer grote onderneming zijn. Het begrip zelfstandige ondernemer in de zin van de beroepstelling dient niet te worden verward met het begrip (kleine) zelfstandige. 
TAв 5 Samenstelling van de Nederlandse beroepsbevolking naar positie in het bedrijf: nijverheid en commerciële diensten (1920-1990)

\begin{tabular}{|c|c|c|c|c|c|c|c|}
\hline & $\begin{array}{c}\text { Totaal } x \\
1.000\end{array}$ & A/totaal & B/totaal & C/totaal & D/totaal & $B+C /$ totaal & $C / D$ \\
\hline 1920 & I. $6 \circ 8$ & $18,9 \%$ & ०,6\% & $2,6 \%$ & $77,8 \%$ & $3,2 \%$ & $3,4 \%$ \\
\hline 1930 & I. 980 & $19,7 \%$ & ०,8\% & $2,8 \%$ & $76,7 \%$ & $3,6 \%$ & $3,6 \%$ \\
\hline I947 & 2.217 & $22,2 \%$ & $0,6 \%$ & $2,6 \%$ & $74,6 \%$ & $3,3 \%$ & $3,5 \%$ \\
\hline 1960 & 2.724 & $\mathrm{I} 2, \mathrm{I} \%$ & $0,9 \%$ & $3,5 \%$ & $83,6 \%$ & $4,3 \%$ & $4,2 \%$ \\
\hline I975 & 3.008 & $8,4 \%$ & $\mathrm{I}, 7 \%$ & $8,3 \%$ & $8 \mathrm{I}, 5 \%$ & IO,I\% & IO,2\% \\
\hline I979 & 3.043 & $8,4 \%$ & $2,0 \%$ & $7,3 \%$ & $82,3 \%$ & $9,3 \%$ & $8,9 \%$ \\
\hline I98I & 3.018 & $8,9 \%$ & $2,2 \%$ & $6,2 \%$ & $82,7 \%$ & $8,4 \%$ & $7,5 \%$ \\
\hline 1985 & 2.850 & $7,6 \%$ & $2,6 \%$ & $7,6 \%$ & $82,2 \%$ & IO,2\% & $9,3 \%$ \\
\hline 1985 & $3.12 \mathrm{I}$ & 8,०\% & $2,4 \%$ & $7,4 \%$ & $82,2 \%$ & $9,7 \%$ & $8,9 \%$ \\
\hline 1990 & 3.880 & $7,9 \%$ & $2,5 \%$ & $8,6 \%$ & 8I,०\% & II,I\% & Iо, $6 \%$ \\
\hline
\end{tabular}

Toelichting: de vetgedrukte data zijn inclusief zakelijke dienstverlening (waaronder vrije beroepen). Bron en toelichting: zie Appendix. tweemaal 1985 ???

Het opvallende aan de Nederlandse situatie is dat het zelfstandig ondernemerschap (de A-posities) in de periode I920-I947, na een aanvankelijke daling in de periode I899-I920, een opgaande lijn vertoont. Mogelijk speelt hierbij de vlucht in zelfstandigheid tijdens de crisis van de jaren dertig, die in I947 nog nagalmde in de statistiek. Daarnaast zijn er gedurende de oorlogsjaren - in ieder geval gedurende I940 en I94I - nog een groot aantal nieuwe ondernemingen opgericht. ${ }^{66}$ Dit is waarschijnlijk een reactie op het Besluit Algemeen Vestigingsverbod Kleinbedrijf (вAVк) dat in I94I door de Duitsers werd ingevoerd. Tussen I947 en I975 is het aandeel zelfstandige ondernemers vrij snel gedaald, vooral in de periode I947-I960. Het in I975 bereikte niveau blijft in de daaropvolgende decennia vrij stabiel. ${ }^{67}$ Van deze ontwikkeling is aanvankelijk slechts een betrekkelijk flauw spiegelbeeld zichtbaar bij de directeuren (B-categorie) ofwel de hogere managers en het overig toezichthoudend en leidinggevend personeel (C-categorie), door ons opgevat als middenmanagers. Tussen I947 en I960 lijkt er hooguit sprake van een lichte stijging van het relatieve belang van de managers (de B- en C-categorie), pas na I960 treden substantiële verschuivingen op, in het bijzonder in het aandeel van de C-categorie.

66. Verslagen van de Ongevallenstatistiek 1930-1942.

67. Het aandeel zelfstandige ondernemers neemt begin jaren tachtig zelfs weer enigszins toe, wat verband zou kunnen houden met de deconcentratie van het Nederlandse bedrijfsleven en een vanaf de jaren zeventig sterk toenemende werkloosheid. Jacques van Gerwen, Zoeken naar zekerheid IV. De welvaarstaat. Volksverzekeringen, verzekeringsconcerns, financiële dienstverleners en institutionele beleggers (Den Haag Amsterdam 2000) I79-I8I. S. Wennekers en M. Folkeringa, The development of the self-employment rate in the Netherlands 18991997 (Zoetermeer 2002). 
In het tijdvak tussen I947 en I960 treedt er met andere woorden vooral een verschuiving van zelfstandige ondernemers naar uitvoerende werknemers op.

De betekenis van de C-categorie blijkt in I975 op een onmiskenbaar hoger peil dan dat van ig6o te zijn beland. De stijging van het aandeel middenkader in een betrekkelijk korte periode van I5 jaar is dermate sterk dat we op deze dimensie van een managerial revolution kunnen spreken. De ontwikkeling is in ieder geval meer schoksgewijs dan die van het aandeel van de voorlieden in de relevante Amerikaanse beroepsbevolking (alleen in de periode I900-I920 vertonen de cijfers in tabel 4 een sprong die enigszins in de buurt komt). De stabilisatie van het aandeel 'middenkader' na I975 suggereert verder dat - anders dan in de VS - de revolutie toen voltooid was. Echter, grote terughoudendheid met het trekken van conclusies is op haar plaats. De Nederlandse cijfers vanaf I975 zijn gebaseerd op enquêtes en zijn minder betrouwbaar dan die van vóór I975. Ook is de vergelijkbaarheid van de gegevens vóór en vanaf I975 kwestieus, met name met betrekking tot de definiëring van categorie $\mathrm{C}$ ten opzichte van de categorieën B en D (zie Appendix). Het is zeer goed mogelijk dat de cijfers vanaf I975 de omvang van categorie C (sterk) overschatten, omdat lagere managers meer dan voorheen zijn meegeteld. Niettemin lijkt de kwantitatieve betekenis van het middenkader in Nederland na I960 serieus te zijn toegenomen. ${ }^{68}$

\section{Conclusie}

In dit artikel hebben wij getracht tot een beter inzicht te komen in het optreden van een managerial revolution. We maakten daarbij een vergelijking tussen de vs en Nederland gedurende een groot deel van de twintigste eeuw. Er bestaan verschillende visies op de managerial revolution. We hebben de materie inzichtelijk gemaakt door drie dimensies van de managerial revolution te onderscheiden, die overigens nauw met elkaar samenhangen. De drie dimensies zijn: de scheiding tussen eigendom en bestuur (I), de professionalisering van het management (2), en de opkomst van het middenkader (3). Op deze manier wordt de beoordeling van het fenomeen managerial revolution systematischer en evenwichtiger dan tot dusver in de literatuur is gebeurd. Het valt op dat het gepubliceerde onderzoek naar de managerial revolution empirisch gezien veel te wensen overlaat. Veelal wordt gewerkt met een beperkte steekproef, waarin grote (industriële) ondernemingen oververtegenwoordigd zijn. De kans om

68. De bovenstaande beschouwingen hebben zoals gezegd betrekking op de nijverheid en de commerciële dienstverlening. Wij hebben afgezien van het presenteren en bespreken van afzonderlijke Nederlandse gegevens over de nijverheid en de dienstensector omdat de trends binnen beide sectoren steeds in dezelfde richting gaan. 
hier gesalarieerde managers aan te treffen is relatief groot en dat heeft auteurs ertoe verleid generalistische uitspraken te doen. Bij nader inzien zijn deze uitspraken echter moeilijk houdbaar gebleken. Vandaar dat wij een eigen empirische bijdrage aan het debat hebben geleverd door op één dimensie, het belang van het middenkader, het bedrijfsleven als geheel te onderzoeken met behulp van nationale beroepstellingen.

Bezien naar de eerste dimensie staat de managerial revolution voor de concentratie van macht bij gesalarieerde managers door een scheiding van eigendom en bestuur. In de VS is de toon van het debat gezet door Berle en Means die in I932 poneerden dat de corporate revolution (zoals zij dat noemden) al een heel eind gevorderd was. Hoewel een geestverwant van deze pioniers in het debat in I966 op basis van een vervolgonderzoek poneerde dat de bewuste revolutie vrijwel voltooid was, hebben latere auteurs dit - in onze ogen overtuigend - verworpen met andere cijfers en interpretaties. Ook het schaarse Nederlandse onderzoek wijst in de richting van een slechts zeer gedeeltelijke scheiding van eigendom en bestuur, zij het dat in het geval van Nederland zich na I960 mogelijk een versnelling van deze scheiding heeft voltrokken.

Onze tweede dimensie is afgeleid van een andere, veel ruimere omschrijving van de managerial revolution dan die van Berle en Means en navolgers, namelijk een totale maatschappelijke omwenteling in de richting van een managed society. De bekendste vertolker van deze ruime interpretatie is Burnham, die in I94I signaleerde dat er sinds I9I4 een nieuwe sociale elite van professionele managers in opkomst was. Wij hebben deze theorie geoperationaliseerd door te kijken naar de hoogte en aard van de scholing van de managers, met name of aan business schools afgestudeerden in het topmanagement zaten. In de praktijk is zowel in de VS als in Nederland de betekenis van de academische scholing van managers zeker tot halverwege de twintigste eeuw zeer beperkt gebleven. Dat geldt nog sterker voor specifiek op managementfuncties gerichte scholing.

Ook Chandler stelt professionalisering van het management centraal, maar anders dan de eerder genoemde auteurs, concentreert hij zich op de groep middle managers, die oplossingen moesten bedenken voor de eind negentiende eeuw optredende problemen van economies of scale, scope and speed. Chandler dateert het begin van de managerial revolution in de vs rond I840 en omstreeks I950 zou deze zijn voltooid. Wij trekken daaruit de conclusie dat het middenkader in die periode in relatieve omvang (sterk) moet zijn gegroeid. Wij hebben deze derde dimensie daarom geoperationaliseerd door te kijken naar het aandeel van de (midden)managers in de totale beroepsbevolking in het bedrijfsleven (exclusief agrarische sector en bepaalde delen van de dienstensector). Hiermee wijken wij uitdrukkelijk af van bestaand onderzoek naar de eerste twee dimensies en komen überhaupt voor het eerst met een empirisch onderzoek naar de derde dimensie. Op basis van het gebrekkige cijfermateriaal over de ontwikkeling van het middenkader met als indicator de 
voorlieden, is het - anders dan Chandler stelt - allerminst evident dat in de VS al omstreeks I950 sprake zou zijn van een voltooide managerial revolution. De cijfers laten in ieder geval tot I970 een verdere toename van het aandeel voorlieden zien. Met behulp van het beschikbare kwantitatieve en kwalitatieve materiaal kan het - ondanks alle tekortkomingen - aannemelijk worden gemaakt dat in ieder geval vóór I960 in Nederland ook op de derde dimensie geen managerial revolution heeft plaatsgevonden. Een toename van het aantal managers (top- en middenkader) in vergelijking met het aantal zelfstandige ondernemers is tot vlak na de Tweede Wereldoorlog niet waarneembaar. De sterke stijging van het aandeel middenkader tussen I960 en I975 is echter wel 'revolutionair', onder voorbehoud van de validiteit en de betrouwbaarheid van de gegevens.

Onze slotsom is dat er zeker in de VS gedurende een groot deel van de twintigste eeuw eerder sprake is van een managerial evolution dan van een managerial revolution. In Nederland lijkt de verschuiving richting management-ondernemingen aanzienlijk later op gang te zijn gekomen dan in de VS. Pas na I960 zijn er aanwijzingen dat er op de eerste dimensie (scheiding eigendom en bestuur) en de derde dimensie (opkomst van het middenkader) een relatief schoksgewijze verandering naar het managerialism is opgetreden, waarmee de Nederlandse ontwikkeling meer het karakter van een managerial revolution lijkt te hebben gehad dan die in de vs.

\section{Over de auteurs}

Hugo van Driel (I962) studeerde maatschappij-geschiedenis aan de Erasmus Universiteit Rotterdam (E U R). Sinds I985 is hij werkzaam aan de Faculteit der Bedrijfskunde van de EUR en specialiseerde zich daar op de haven- en transportsector (promotie I990). Hij vervulde tevens twee postdoc-schappen, respectievelijk bij de vakgroep Filosofie van Wetenschap en Techniek van de Universiteit Twente in het kader van het project 'Techniek in Nederland in de Twintigste Eeuw' (I998-2000) en - via de Faculteit der Historische en Kunstwetenschappen van de E U R - in het kader van een comparatief Vlaams-Nederlands onderzoeksproject over havenconcurrentie tussen Rotterdam en Antwerpen I880-2000 (200I-2002).

E-mail: h.driel@fbk.eur.nl

Jacques van Gerwen (I956) is vanaf I985 als onderzoeker werkzaam bij het Nederlandsch Economisch-Historisch Archief (NEHA). Sinds I994 maakt hij deel uit van de redactie van het TSEG en de voorloper, het NEHA-Jaarboek. Zijn huidige onderzoeksactiviteiten betreffen de economische en bedrijfsgeschiedenis in het algemeen, Nederlandse ondernemers en ondernemerschap in het bijzonder. Binnen het kader van het B I NT-project (http://www.bintproject.nl/) 
onderzoekt hij samen met dr. F. de Goey de Nederlandse ondernemers en het Nederlandse ondernemerschap.

E-mail: jge@iisg.nl

Ferry de Goey (I959) is verbonden aan de Opleiding Geschiedenis van Faculteit der Historische en Kunstwetenschappen (Erasmus Universiteit) en specialiseert zich in bedrijfsgeschiedenis. Hij publiceerde recent ondermeer: Ferry de Goey (ed.), Comparative port history Rotterdam-Antwerp, 1880-2000. Competition, cargo, and costs (Amsterdam 2004); Ferry de Goey, 'Ford in the Netherlands, I903-2003. Global strategies and national interests', in: H. Bonin, Y. Lung en S. Tolliday (eds.), Ford. The European history 1903-2003 (Paris 2003); Ferry de Goey en Jan Willem Veluwenkamp (eds.), Entrepreneurs and Institutions in Europe and Asia, 1500 - 2000 (Amsterdam 2002) en Ferry de Goey, 'Henri Deterding, Royal Dutch/Shell and the Dutch market for petrol', in: Business History (2002).

E-mail: degoey@fhk.eur.nl 


\title{
APPENDIX: TOELICHTING TABEL 5
}

\section{Bronnen}

С в, Volkstelling 31 december 1920. Uitkomsten beroepstelling. Bedrijfsindeeling (Den Haag I924).

свS, Volkstelling 31 December 1930. Deel VII. Uitkomsten van de beroepstelling. Bedrijfsindeeling (Den Haag 1934).

С BS, 12 Volkstelling 31 december 1947. Beroepstelling (Utrecht I952).

С вs, 13e Algemene volkstelling 31 mei 1960. Deel 10. Beroepsbevolking. A. Algemene inleiding

(Den Haag I967).

С в , Arbeidskrachtentellingen 1975, 1977, 1979, 1981, 1983, 1985.

Свs, Enquête Beroepsbevolking 1990.

\section{Toelichting}

\begin{abstract}
Algemeen - tot en met 1947 niet meegeteld. tot en met I947, waarbij:

$\mathrm{A}=$ zelfstandigen

$\mathrm{B}=$ directeuren

$\mathrm{C}=$ (ander) toezichthoudend en leidinggevend personeel

$\mathrm{D}=$ uitvoerende werknemers
\end{abstract}

De cijfers hebben steeds betrekking op de werkzame beroepsbevolking, dus exclusief werkzoekenden. Behalve de agrarische sector zijn tevens de sectoren buiten beschouwing gelaten waarvoor in de beroepstellingen tot en met 1947 geen onderverdeling is gemaakt naar A, B, C en D (zie onder). ${ }^{69}$ Alleen in I990 zijn de zakelijke diensten wel meegerekend. Ook de groep 'losse werknemers' is - om dezelfde reden

Uitgangspunt voor het maken van de tabel was de onderverdeling in vier categorieën personeel naar 'positie in het bedrijf die gemaakt wordt in de beroepstellingen

69. Het betreft: de vrije beroepen en andere 'overige dienstverlening', zoals bepaalde vormen van zakelijke dienstverlening (accountantsbureaus, reclamebureaus, advocatenkantoren, ingenieursbureaus), huiselijke diensten, het ambtelijke apparaat, de kerken, het onderwijs, de kunstsector, sport, de gezondheidszorg en het leger. In I920 en I930 onderscheiden de beroepstellingen ook nog een groep $\mathrm{E}$ van werknemers met beroepen die niet typerend waren voor de bedrijfstak waarin ze werkten (zoals bijvoorbeeld voerlieden). Deze groep is door ons toegevoegd aan groep D, waardoor deze groep vergelijkbaar wordt met die in 1947. 
$\mathrm{Na}$ I960 hebben wij de gegevens uit de beroepstellingen en enquêtes zelf volgens dit stramien ingedeeld (zie onder). De meest recente door ons gepresenteerde gegevens betreffen het jaar I990. Latere enquêtes zijn niet gedetailleerd genoeg voor een indeling in $\mathrm{At} / \mathrm{m} \mathrm{D}$.

\section{Beroepstellingen 1920-1947}

Voor een goed inzicht in het middenmanagement is gedetailleerde kennis over de samenstelling van de C-categorie van groot belang. In de beroepstellingen van vóór I920 bevatte de C-categrie ook al het administratief personeel. Vandaar dat de beroepstellingen pas vanaf I920 bruikbaar zijn voor onze doeleinden. In I920 zijn tevens 'voorlieden, ploegbazen e.d.' voortaan tot de 'gewone werklieden' (D) gerekend in plaats van C. De omschrijving van categorie $C$ in de beroepstellingen van I920 t/m I947 luidt: 'bedrijfsleiders, meesterknechten e.d.'. Het is niet duidelijk wat nu het precieze onderscheid was tussen meesterknechts enerzijds en ploegbazen en voorlieden anderzijds. Bekend is verder dat filiaalhouders en zetbazen in I920 niet langer tot $\mathrm{B}$, maar tot $\mathrm{C}$ werden gerekend, hetgeen vooral relevant was voor de bedrijfsklassen handel en verkeer. Tot slot blijkt uit de toelichting bij de beroepstelling van I960 dat tot en met I947 ook de zogenaamde werkmeesters tot groep C werden gerekend. Werkmeesters stonden een stap hoger in de hiërarchie dan de 'bazen'; ${ }^{\circ}$ zij horen dus ondubbelzinnig tot de categorie middenmanagement.

\section{Beroepstelling 1960}

Uit oogpunt van vergelijkbaarheid zijn in I960 behalve 'andere maatschappelijke diensten', ook 'maatschappelijke en zakelijke dienstverlening, recreatie-, horecabedrijven e.d.' niet meegenomen. Dit is noodgedwongen niet helemaal consequent, want de horeca is voor en na ig6o wel meegeteld.

In de beroepstelling van I960 is de onderverdeling in A, B, C en D losgelaten en moesten wij uitgaan van beroepen. Daarbij bestaat veelal de zekerheid dat de betrokken personen in een bepaalde sector (nijverheid of diensten) werkzaam waren (dit geldt met name voor ' $\mathrm{C}$ ', zie hieronder). A is gelijkgesteld aan 'bedrijfshoofden' (tabel 2 uit de Beroepstelling 1960, deel IoA). Verder hebben wij bepaalde beroepscategorieën uit tabel 7 toegewezen aan $B$ en $C$, terwijl $\mathrm{D}$ bepaald is door het aftrekken van de som van $A, B$, en $C$ van de totale beroepsbevolking in de betrokken sectoren. De toedelingen zijn als volgt geschied:

B: bedrijfshoofden (voor zover niet zelfstandig) en directeuren NV e.d.:

II2 industriëlen, aannemers

II3 Handelaren

II4 bank, verzekeringswezen en woningexploitatie

II5 transport of communicatie 
C: bedrijfsleiders en overige beleidvoerend en leidinggevend personeel werkzaam in de sectoren:
I22/132 nijverheid e.d.
I23/I33 handelsbedrijven
I24/I34 bank, verzekeringswezen of woningexploitatie
I25/135 transport of communicatie de werkmeesters

Volgens de toelichting hadden zowel de bedrijfsleiders als het overige beleidvoerend en leidinggevend personeel (door ons toegekend aan C) betrekking op functionarissen die rechtstreeks onder het bedrijfshoofd of directeur leiding gaven aan een bedrijf of deel ervan. Nogal vaag wordt er aan toegevoegd dat verder een aantal van deze personen aan 'andere eveneens onder de employés vallende beroepen' is toebedeeld. ${ }^{71} \mathrm{De}$ telling bevat tevens een afzonderlijke opgave van het totale aantal werkmeesters, een categorie die tot en met I947 (grotendeels) tot C is gerekend, ${ }^{72}$ te weten 4I.000. Daarom zijn de werkmeesters door ons meegeteld in Categorie C.

\section{Arbeidskrachtentellingen 1975-1985 en Enquête Beroepsbevolking 1990}

De arbeidskrachtentellingen en de enquête beroepsbevolking I990 zijn steekproeven (variërend van 2,5 tot 5 procent van de totale populatie) en geen integrale tellingen. De betrouwbaarheid van de uitkomsten laat mede hierdoor te wensen over: het св signaleert in verschillende jaren onwaarschijnlijke schommelingen in de aantallen personen in bepaalde categorieën. ${ }^{73}$ Om de effecten van die sterke schommelingen voor de door ons berekende percentages te laten zien, hebben wij verscheidene dicht op elkaar gelegen jaren in de tabel opgenomen en niet alleen de ronde jaren I975, I985 en I990. Daarbij is van belang dat de cijfers minder precies zijn dan in de beroepstellingen. Het betreft telkens afrondingen op duizendtallen, waardoor - ook door het aggregeren van cijfers - vertekeningen kunnen ontstaan.

Tot I990 bleek het mogelijk de deelsector 'zakelijke dienstverlening' buiten beschouwing te laten. Voor de jaren I975 en I98I is het aantal zelfstandigen in de zakelijke dienstverlening bepaald door toepassing van de verhouding van het aantal zelfstandigen in 'bank- en verzekeringswezen, zakelijke dienstverlening' en 'zakelijke dienstverlening' in I979, het meest dichtbij gelegen jaar dat de zelfstandigen verfijnd per bedrijfsklasse gegeven zijn.Voor het jaar I990 ontbreken afzonderlijke opgaven van $\mathrm{B}$ en $\mathrm{C}$ voor de zakelijke dienstverlening, zodat het uitsluiten van deze categorie niet mogelijk is.

Zeer belangrijk is dat de indeling van de beroepen en de beroepspositie afwijkt van de eerdere tellingen met betrekking tot de B's en de C's. ${ }^{74}$ Hieronder is uiteengezet hoe wij die B's en C's hebben bepaald. Belangrijk daarbij is dat wij-conform de tot dusver

71. Beroepstelling 1960, deel 6A, blz. 27.

72. Dit wordt althans gesuggereerd in Beroepstelling 1960, deel IoA, tabel 8 waarin cijfers van I947 en I960 met elkaar vergeleken worden.

73. Arbeidskrachtentelling 1977, I7 en Arbeidskrachtentelling 1983, I6.

74. Het св s beschikt helaas niet over gedetailleerdere gegevens dan gepubliceerd in de Arbeidskrachtentellingen, zodat het niet mogelijk was de vergelijkbaarheid met de tellingen van voor 1975 te vergroten met behulp van niet gepubliceerd materiaal. 
gevolgde methode - gekeken hebben naar het voorkomen van deze categorieën in een bepaalde sector (nijverheid of diensten) en niet naar de naam van de bewuste categorie zelf. Bijvoorbeeld: 'agrarische directeuren' zijn deels toegewezen aan de nijverheid op basis van de tabellen 'Werkzame personen naar bedrijfs- en beroepsklasse'. In het geval van de bedrijfsenquête I990 is van een deel van de per beroepscategorie genoemde aantallen niet bekend tot welke sector ze behoren, soms zelfs voor too procent (bijvoorbeeld agrarische directeuren).

Voor de jaren I975 t/m I990 is in eerste instantie de volgende toedeling gemaakt:

A: Zelfstandigen

B: Directeuren en bedrijfsleiders

$\begin{array}{ll}40 & \text { Groothandel } \\ 4 \mathrm{I} & \text { Detailhandel } \\ 50 & \text { Horeca } \\ 60 & \text { Land- en tuinbouw (alleen bedrijfsleiders) } \\ 68 & \text { Directeuren landbouw }\end{array}$

C: Beleidvoerend, toezichthoudend en leidinggevend personeel:

2I Beleidvoerend en hoger leidinggevend, exclusief openbaar bestuur

30 Administratief

35 Transport en communicatie

45 Commercieel, inkopers

52 Huishoudelijk personeel

70 Productiepersoneel

D: Totale beroepsbevolking minus A,B en C.

Uit dit overzicht blijkt dat 'bedrijfsleiders' - als onderdeel van een ongesplitste categorie - door ons zijn toegekend aan B en niet aan C zoals in I960 omdat dat dit aansluit bij de door het Св gebruikte benamingen van vóór I960 (indien bedrijfsleiders in I960 worden toegerekend aan de B-categorie, dan wordt B groter dan of even groot als C). Daarnaast is het aantal genoemde personen in categorieën 2I en 45 verminderd met het aantal zelfstandigen in deze categorieën (zoals in feite ook in I960 in vergelijkbare categorieën is gedaan). Dit aantal zelfstandigen kon geschat worden met behulp van gegevens in een andere tabel waarin per categorie het aantal zelfstandigen staat aangegeven; het aantal per categorie af te trekken zelfstandigen is bepaald op basis van het aandeel van alle zelfstandigen in nijverheid en dienstverlening in het totaal aantal zelfstandigen in dat jaar. Overigens bestaat alleen categorie 2I voor een significant deel uit zelfstandigen.

De tellingen onderscheiden geen categorie 'directeuren in de nijverheid' (en trouwens ook niet in banken en verzekeringen), waardoor de nijverheid het voor de B's geheel van de niet-nijverheidsdirecteuren moest hebben, waarbij de horeca- en agrarische directeuren (!) de voornaamste bijdrage leveren. De aanvankelijke toedeling resulteerde zo in een onwaarschijnlijk laag aandeel B's in de nijverheid $(0,2$ tot 0,3 procent) in vergelijking met de jaren tot en met I960 (toen het aandeel schommelde tussen de 0,5 en 0,7 procent). Zeer waarschijnlijk zitten er ook (nijverheids)directeuren verscholen in categorie 2I, beleidvoerend en hoger leidinggevend personeel, exclusief openbaar bestuur. Het niet onbelangrijke aandeel zelfstandigen in deze categorie wijst 
daar al op. Daarom hebben we in tweede instantie besloten een deel van categorie 2I toe te wijzen aan 'B'. Hierbij hebben wij ons gebaseerd op de globale verhouding tussen de aantallen B en $\mathrm{C}$ in de jaren I920-1960. Op basis hiervan is van categorie $2 \mathrm{I}$ in de nijverheid 20 procent toegekend aan $\mathrm{B}$ en in de dienstensector 25 procent.

Het is niet bekend of 'lagere' managers zoals voorlieden en ploegbazen, die in de beroepstellingen tussen I920 en I960 niet tot ' $C$ ' (of de categorieën die door ons aan C zijn toebedeeld) zijn gerekend maar tot 'D', vanaf I975 wél zijn gerangschikt in de diverse categorieën beleidvoerend, toezichthoudend en leidinggevend personeel. Dit is een vitaal punt omdat het aantal voorlieden, ploegbazen en dergelijke per definitie een veelvoud is van het aantal 'echte' middenmanagers (zoals bijvoorbeeld de 'werkmeesters' uit de beroepstellingen tot en met I960). Anderzijds zijn in ieder geval tot en met I947 volgens de categorie-aanduidingen van de beroepstelling functionarissen zoals 'meesterknechts' wel degelijk tot $\mathrm{C}$ gerekend. Kortom, de vergelijkbaarheid van de categorie $\mathrm{C}$ voor en vanaf I975 is kwestieus, maar het is niet noodzakelijk zo dat de omvang van deze categorie vanaf I975 zwaar is overschat in vergelijking met eerdere meetjaren. 